\title{
The role of type 1 angiotensin 2 receptor polymorphism in asthmatic patients
}

\author{
Margarida Cortez ${ }^{1 *}$, Andreia Matos², Joana Ferreira², Leonor Lopes², Angela Gill ${ }^{2}$, Manuel Bicho² \\ From EAACI International Severe Asthma Forum (ISAF 2012) \\ Gothenburg, Sweden. 11-13 October 2012
}

\section{Background}

It is known that type 1 angiotensin II (Ang II) receptor (AGTR1) could be related with the pathogenesis of bronchial asthma. It is involved in Th polarization, through different signaling pathways modulating allergic airway inflammation, and also may participate in airway remodeling and bronchoconstriction, that could be related with AGTR1 polymorphism. The purpose of this study is to analyze the association between AGTR1 1166A/C (rs5186) gene polymorphism with asthma severity.

\section{Methods}

Asthmatic patients : $\mathrm{n}=37$; were compared with a control group of $\mathrm{n}=32$ healthy blood donors. The AGTR1 1166A/C (rs5186) gene polymorphism was determined by PCR-RFLP (polymerase chain reaction- restriction fragment length polymorphism). Control of asthma assessed by validated instrument (ACQ7 and PAQLQ). Statistical analysis was performed with PASW version 18 establishing a significance level of $\mathrm{p}<0.05$.

\section{Results}

The mean age of the 37 asthmatics was $40 \pm 18$ years; minimum 7 and maximum 71; 24 females and 13 males; 35 Caucasians and 2 non-Caucasians; 34 atopics and 3 non-atopics; 22 with controlled and 15 with uncontrolled asthma. The control group for this polymorphism is in Hardy-Weinberg equilibrium ( $>0.05$ ). In asthmatics the frequencies of the allele $\mathrm{A}$ is $53 \%$ and the allele $\mathrm{C}$ is $47 \%$; in controls: $64 \%$ and $36 \%$ respectively. There is no statistical difference between these groups ( $p>0.05)$. Genotypes in the asthmatics- AA: 29.7\%; AC: $46 \%$; CC: $24.3 \%$; in control group- AA: $34.4 \%$; AC: $59.4 \%$; CC: $6.2 \%$. There is no statistical difference between these groups ( $>>0.05$ ). When we associate AGTR1 genotypes, there was a

${ }^{1} \mathrm{CHLN}-\mathrm{HSM}$, Portugal

Full list of author information is available at the end of the article tendency, but not significant, between asthmatics and controls ( $\mathrm{CC}$ vs $\mathrm{AC}+\mathrm{AA} ; \mathrm{p}=0.086)$ being $\mathrm{CC}$ genotype more frequent in the asthma-group. In asthmatics, there is no statistical difference $(\mathrm{p}>0.05)$ in genotypes: between atopics and non atopics; controlled and uncontrolled asthma; males and females; by ethnic-group; and in the different age-groups.

\section{Conclusions}

Our findings provided some evidence that there is a trend, although not significant, that AGTR1 gene A1166C polymorphism might be a genetic marker for the pathophysiology of allergic airway inflammation, remodeling and bronchoconstriction in asthmatic disease.

\section{Author details}

${ }^{1}$ CHLN-HSM, Portugal. 'Lisbon Medical School, Genetic Department, Portugal.

Published: 3 May 2013

\section{doi:10.1186/2045-7022-3-S1-P17}

Cite this article as: Cortez et al:: The role of type 1 angiotensin 2 receptor polymorphism in asthmatic patients. Clinical and Translational Allergy 2013 3(Suppl 1):P17.

Submit your next manuscript to BioMed Central and take full advantage of:

- Convenient online submission

- Thorough peer review

- No space constraints or color figure charges

- Immediate publication on acceptance

- Inclusion in PubMed, CAS, Scopus and Google Scholar

- Research which is freely available for redistribution 